\title{
Pharmacognostical Study of Combretum aculeatum Vent. Growing in Sudan
}

\author{
Original \\ Article Kamal M. Hamad, Manal M. Sabry, Sabah H. Elgayed, \\ Abdel-Rahman El Shabrawy, Ahlam M. El-Fishawy
}

Department of Pharmacognosy, Faculty of Pharmacy, Cairo University, Egypt.

\begin{abstract}
Aim of Study: Combretum aculeatum Vent is commonly used in traditional medicine but no published botanical characterization was available. Macro- and microscopical characters of the aerial parts (leaf, stem and bark) have been studied with the aim to find the diagnostic features, and pointed towards their identification in both entire and powdered form.

Results: Proximate analysis like moisture contents (7.52\%), total ash (14.09\%), water-soluble ash $(0.7 \%)$, acid-insoluble ash $(2.99 \%)$ and alcohol soluble extract $(9.5 \%)$ were determined. Percentage yield of sequential extractive values of sample in petroleum ether $(1.85 \%)$, methylene chloride $(0.92 \%)$, ethyl acetate $(2.2 \%)$ and n-butanol $(1.66 \%)$ were also evaluated. Total phenolic content was found to be $2.47 \mu \mathrm{g} \mathrm{GAE} / \mathrm{mg}(0.25 \%)$ and total flavonoid content $7.96 \mu \mathrm{g}$ QE/mg $(0.8 \%)$ of dried ethanolic extract. The phenolic and flavonoids profiles of the ethanolic extract were determined using HPLC. Luteolin, naringin and quercetin were the major identified flavonoids and ellagic acid and vanillic acid were the major identified phenolic compounds. Ethanolic extract, as well as its subfractions (petroleum ether, methylene chloride and ethylacetate/ butanol) showed significant molluscicidal activity against the snails of Biomphalaria at dose of $1 \mathrm{mg} / \mathrm{ml} \mathrm{and} 1.2 \mathrm{mg} / \mathrm{ml} \mathrm{and}$ anthelmintic activity against Toxocara vitrurorum worm.
\end{abstract}

Received: 10 August 2018, Accepted: 04 Feb 2019

Key Words: Anthelmintic, botanical study, combretum aculeatum Vent, HPLC, molluscicidal activity, pharmacognostical standardization.

Corresponding Author: Manal M. Sabry, Department of Pharmacognosy, Faculty of Pharmacy, Cairo University, Egypt, Tel.: +20 1001918735, E-mail: manal.sabry@pharma.cu.edu.eg.

Bulletin of Faculty of Pharmacy, Cairo University, ISSN: 1110-0931, Vol. 57, No. 2

\section{INTRODUCTION}

In developing countries herbal drugs play an important role in health care programs. However, obstacle behind acceptance of alternative medicine, in developed countries is the lack of documentation and standardization of raw materials used in herbal medicine so botanical study was globally accepted in identification and authentication of the genuine plant materials ${ }^{[1]}$.

Combretum aculeatum Vent. Family Combretaceae is one of popular medicinal plants distributed in Sudan, kordofan and South Darfour ${ }^{[2]}$. Combretum aculeatum Vent. has synonyms; Combretum leuconili Schweinf., C. holstii Engl., C. denharbretum Engl. and Diels, C. stefaninanum Pamp, and common name is shieheit and dablab (Arabic Sudan). The plant is a large woody climbing shrub, has long sarmentose branches, the bark is fibrous grey-beige or dark red, with brown rhytidome. The leaves are simple alternate with persistant petioles forming recurved thorns allowing the plant to hook on to surrounding trees and shrubs after the rest of the leaf has fallen. The inflorescence is spike-like formed of yellowishwhite fragrant bisexual flowers, the fruits are one drupelike with broad membranous wings ${ }^{[3,4]}$.
The plant is used traditionally for its purgative, diuretic, colic, diarrhea, intestinal, blenorrehoea, wounds, fever, gastritis, intestinal worm, female sterility and mental disorders. Senegal used root-decoction in catarrh and stem bark to heal wound and to promote urination in venereal diseases and obstruction of urethra. In Ethiopia the leaves are used as anthelmintic while its branches are used to facilitate teething in children, eye problem and dysentery. In Sudan bark, leaves and seeds extracts are used to treat tuberculosis of the skin ${ }^{[3]}$.

Reviewing the available current literature, Several species of genus Combretum have been investigated for their phytochemistry viz., terpenoids, phenolic compounds (flavonoids, phenanthrene, stilbenes and tannins ${ }^{[5-8]}$ and for their biological activity viz.; antibacterial, antiviral and antimalarial ${ }^{[9,10]}$. Pharmacognostical standardization for Combretum aculeatum Vent. is lacking. The present study is to establish the botanical characters of the different organs of the plant and to perform a qualitative HPLC analysis and a quantitative determination of total phenolic and flavonoid content of the plant to allow identification, authentication and discrimination of the genuine plant materials from other Combretum species to confirm its safety in traditional uses. 


\section{MATERIALS AND METHODS}

\section{Plant material}

The aerial parts (stems, leaves, and bark) of Combretum aculeatum Vent. were collected in October 2013 from Basunga, Gadarif State, Sudan. Plant identity was kindly authenticated by Dr. Haider Abd Kadeir Assistant Professor of Plant Taxonomy at Medicinal and Aromatic Plants Research institute (MAPRI), Sudan. Specimens for morphological studies were dried according to standard herbarium techniques and voucher samples (15.11.15.1) are kept at the Museum of the Pharmacognosy Department, Faculty of Pharmacy, Cairo University.

\section{Botanical study}

Photographs were taken using Sony Digital camera. Anatomical investigations were performed on crosssections of the leaf, stem and bark which were preserved in alcohol $(70 \%)$ containing 5\% glycerin were used. Airdried samples were reduced to powder No.36 and saved for microscopical examination. The photographs were taken using microscope with digital camera (Leica microsystems, Germany). Histochemical tests were performed for the presence of lipophilic substances (suddan III), phenolic compounds (ferric chloride), starch (iodine) and lignin (phluroglucinol and hydrochloric acid).

\section{Phytochemical Study}

\section{Determination of certain pharmacopoeial constants}

Moisture content, total ash, water soluble ash, acidinsoluble ash and ethanol soluble extractive had been carried out on the aerial parts following the procedure of the ${ }^{[11]}$. The results are listed in table 3 .

\section{Percentage yield of the extractives}

The air dried powdered aerial parts $(30 \mathrm{~g})$ was subjected to Soxhlet extraction with petroleum ether $\left(60-80^{\circ} \mathrm{C}\right)$ followed by successive extraction with methylene chloride, ethyl acetate and n-butanol saturated the extracting solvents were evaporated under vacuum to yield the petroleum ether, methylene chloride, ethyl acetate and n-butanol extractives ${ }^{[12]}$. The percentage yields of the extractives were computed based on dry weight of plant material, the organoleptic characters of the dried extract were observed. In addition, all extractives were subjected to chemical tests to investigate their constituents. All results are listed in table 4 .

\section{Total phenolics and flavonoids content}

The total phenolic content of the plant ethanolic extract was determined according to the method described by Andressa Blainski ${ }^{[13]}$. A mixture of $100 \mu \mathrm{L}$ of plant extract, $500 \mu \mathrm{L}$ of Folin-Ciocalteu reagent and $1.5 \mathrm{ml}$ of $\mathrm{Na} 2 \mathrm{CO} 3$ $(20 \%)$ was shaken and diluted up to $10 \mathrm{ml}$ with water. The absorbance was measured after $30 \min$ at $\lambda \max 765 \mathrm{~nm}$, the total phenolic content was expressed as $\mu \mathrm{g}$ of gallic acid equivalents ( $\mu \mathrm{g}$ GAE /mg of dried extract).
Total flavonoids content was determined by aluminum chloride $^{[11]}$. Quercetin was used as standard. An aliquot $(0.8 \mathrm{ml})$ of ethanolic extract $(1 \mathrm{mg} / \mathrm{ml})$ was mixed with 1.5 $\mathrm{ml}$ methanol, $0.1 \mathrm{ml}$ aluminum chloride, $0.1 \mathrm{ml}$ potassium acetate solution and $2.8 \mathrm{ml}$ distilled water. The absorbance of the resulting solution was measured after $30 \mathrm{~min}$ at $\lambda$ max415, the total flavonoids content was expressed as $\mu \mathrm{g}$ of quercetin equivalents ( $\mu \mathrm{g} \mathrm{QE} / \mathrm{mg}$ of dried extract).

\section{HPLC analysis of flavonoids and other phenolic compounds}

HPLC analysis of the flavonoids and other phenolic compounds was achieved on zorbax ODS P18 column (particle size $5 \mu \mathrm{m}, 250 \mathrm{~mm} \times 4.6 \mathrm{~mm}$ ). Column temperature was maintained at $35^{\circ} \mathrm{C}$. Flavonoids separation was done using a mobile phase consisting of $5 \mathrm{M} \mathrm{H} 3 \mathrm{PO} 4, \mathrm{pH} 2.5$ (solution A) and acetonitrile (solution B) in gradient mode. The flow rate of the mobile phase was $0.7 \mathrm{ml} / \mathrm{min}$. The phenolic compounds were separated using a solvent system consisting of A (aqueous acetic acid 2.5\%), B (aqueous acetic acid 8\%) and $\mathrm{C}$ (acetonitrile) in gradient mode. The solvent flow rate was $1 \mathrm{ml} / \mathrm{min}$ and the injection volumes were $5 \mu 1$. Ultraviolet detector was set at $330 \mathrm{~nm}$ for flavonoid and $280 \mathrm{~nm}$ for phenolic compounds ${ }^{[14]}$.

\section{Biological Study}

\section{Estimation of molluscicidal activity}

Biomphalaria Alexandria snails (0.6-1 cm diameter) were collected from Abu-Rewash (Giza Provence). The snails, apparently free of trematoda infection, were selected and left in clean dechlorinated water for hatching adopting the technique of Amin and Aboubaker, 2017 ${ }^{[15]}$. Results are illustrated in table 5 .

\section{Estimation of anthelmintic activity}

Adult Toxocara vitrurorum worm were collected from the intestine of slaughtered calves in El- bassatin and Embaba abattoir then dissected to collect T. vitulorum eggs. Results are illustrated in table 6 .

\section{RESULTS}

\section{Botanical Profile}

\section{Macromopohology (Figure 1A)}

Combretum aculeatum Vent is an ever green scrambling shrub that subsists often on its annual shoots. It reaches up to 4-6 $\mathrm{m}$ in height and about $25 \mathrm{~cm}$ in diameter. It has long sarmentose branches (Figure 1B).

\section{The leaf (figure $1 C$ and D)}

The leaf is simple, cauline, alternate, shortly petiolate, exstipulate and green in colour, (up to $5-7 \mathrm{~cm}$ in length and $3-5 \mathrm{~cm}$ in width) the upper surface is darker than the lower surface. The lamina is elliptic to obovate in shape, with acute to acuminate apex, symmetric base and entire margin. The surface is more or less pubescent showing pinnate reticulate venation with the midrib prominent to 
the lower surface. The petiole is $1-10 \mathrm{~mm}$ long, and persist after the rest of the leaf fallen, forming a recurved spine up to $30 \mathrm{~mm}$ long allowing the plant to hook surrounding trees and shrubs.

\section{The stem (Figure 1A and B)}

The trunk and big branches are erect, solid, hard, woody, cylindrical and covered with thicken greyishbrown to brown color bark showing longitudinal cracks and sometimes transverse ones. The old branches are stiff, woody and rough, usually showing longitudinal wrinkles
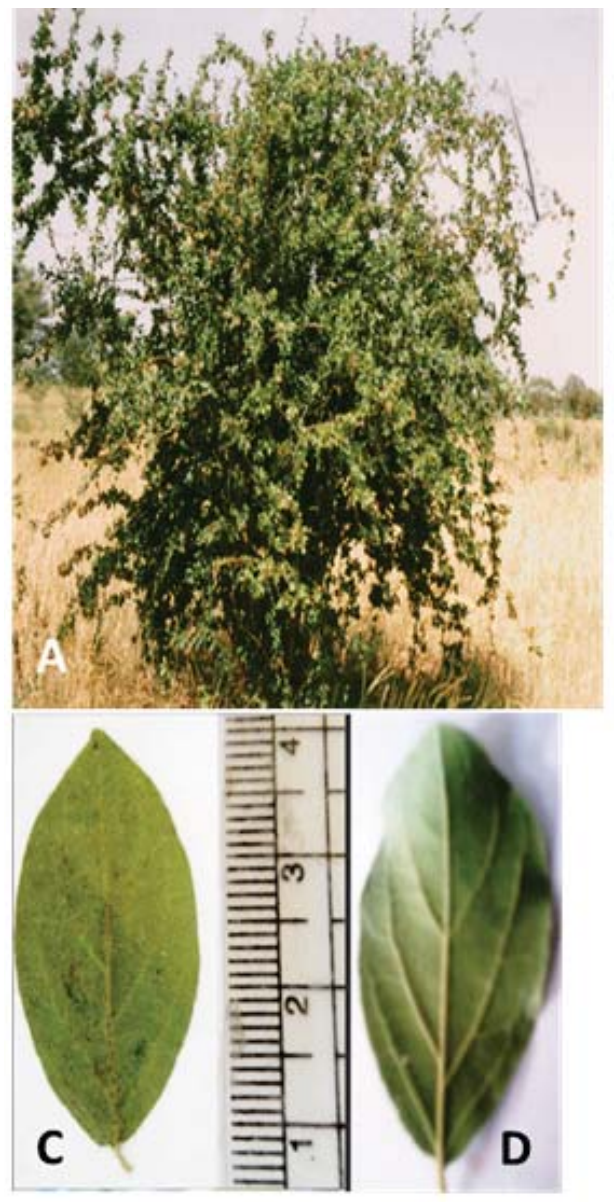

at intervals. Fibrous tough fracture and show solid interior. The young branches are herbaceous, green in color, pubescent, with short internodes up to $2.5 \mathrm{~cm}$ in length, flexible fracture exposing green interior.

\section{The bark (Figure $1 E$ and F)}

The bark is fibrous grey or dark red with brown rhytidoma showing longitudinal wavy and deep fissures, transverse cracks and raised lenticel. The inner surfaces are pale yellow in color showing longitudinal striation.
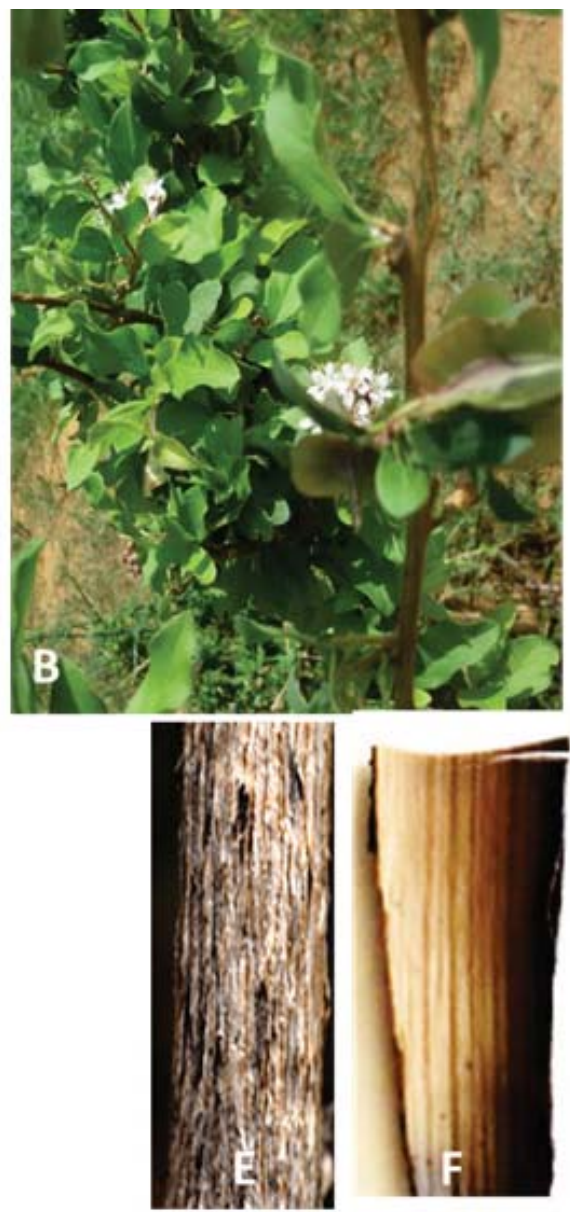

Fig. 1: Combretum aculeatum Vent; A Photograph of the shrub (X0.15); B Branch showing leaves and its axial inflorescence (X 0.22), C and D Upper and lower surfaces of the leaf (X 1.7); E\& F Outer and inner surfaces of bark (X 1.9) 


\section{Micromorphology}

\section{The leaf}

3.1.2.1.1. A Transverse section (Figure 2A) showed a biconvex midrib being more prominent on the lower side, a merestele and lateral laminar dorsiventral on its either side. The epidermal cells are polygonal isodiametric with straight beaded anticlinal walls in the upper surface, slight wavy on the lower one, axially elongated in the midrib region and covered by thin smooth cuticle. Stomata of anomocytic type are present on both surfaces and more frequent on the lower one. Trichomes on both surfaces are mostly of the non-glandular type and occasionally of the glandular type. Non-glandular hairs are, simple, unicellular, often somewhat bulbous at the base, more or less conically or convexly arched outwards towards the filiform part (Combretaceous hair). While glandular hair is very rare they have short or elongated stalked and spherical or bladder-like head.

The mesophyll tissue (Figure 2C) is differentiated into 2-3 rows of palisade on the upper side, discontinuous in the midrib region followed by loosely arranged 4-6 rows of spongy parenchymatous tissue. Idioblast containing clusters of calcium oxalate are scattered in the palisade tissue.

The upper and lower cortical tissues of the midrib (Figure 2B) consist of 2-3 rows of collenchyma followed by 5-6 rows of large thin-walled parenchymatous cells. The midrib region is traversed by a bicollateral arc-shaped vascular bundle surrounded by groups of lignified pericyclic fibers interrupted by small areas of parenchymatous cells. The pericyclic fibers are fusiform with thick lignified, straight or undulating wall, narrow lumen and acute apex. The phloem tissues in both the outer and inner phloem are composed of soft thin-walled phloem elements traversed by uniseriate to rarely biseriate medullary rays. The xylem tissues are lignified composed of vessels, tracheidial vessels, wood fibers and wood parenchyma. The xylem vessels are arranged in radial rows and show spiral, pitted and annular thickenings. Tannin cells and tubes, numerous clusters of calcium oxalate and starch grains are scattered in the cortical, mesophyll and phloem tissues.

\section{The powdered leaf (Figure 2D)}

The powder is greyish green in color, odorless and has a stringent taste. It is characterized by the following features: fragments of upper and lower epidermises showing anomocytic stomata, abundant unicellular non-glandular (Combretaceous hair) and few glandular club shaped trichomes; large idioblast containing cluster of calcium oxalate beside numerous clustered crystals of calcium oxalate; spiral and annular lignified xylem vessels; tannins cells or tubes; fragments of pericyclic fibers and palisade cells.

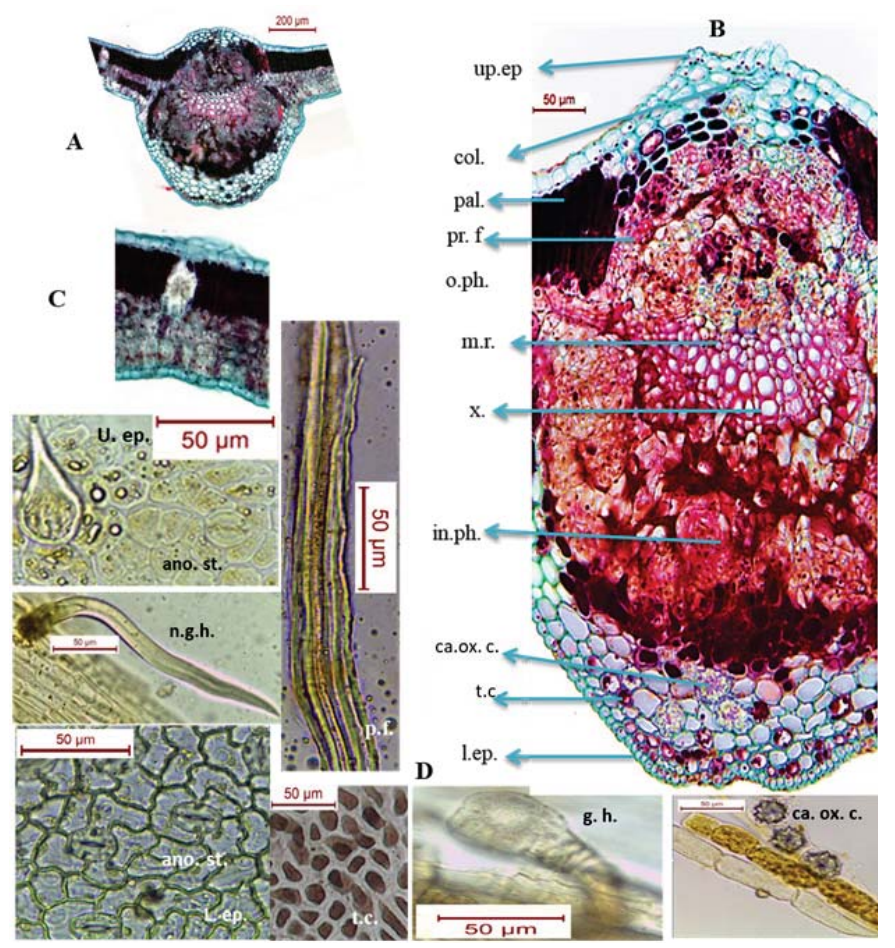

Fig. 2: Leaf of Combretum aculeatum Vent. A. low power view of the lamina (X40); B High power view of the midrib (X165); C.

High power view of the lamina (X120); D. Powdered leaf an. st., anomocytic stomata; ca. ox.c, calcium oxalate cluster; col., collenchyma; g.h., glandular hair; in. ph., inner phloem; l.ep., lower epidermis; m.r. medullary ray; n.g.h., non glandular hair; o.ph., outer phloem; u.ep., upper epidermis; pal., palisade; pr.f., pericyclic fibers; in.ph., inner phloem; t.c., tannin cells; ; t.tu., tannins tubes; x., xylem. 


\section{The stem}

\section{The old stem branches (Figure 3A-B)}

A transverse section in the old branches is nearly circular in outline. It consists of a somewhat wide layer of cork followed by a narrow region of secondary cortex surrounding the well-developed vascular system.

The cork arises in the pericycle region and is formed of several radial rows of tangentially elongated, polygonal brown cork cells with lignified walls. The vascular tissue consists of continuous ring of bicollateral vascular bundles separated by distinguishable cambium and traversed by uniseriate medullary rays. The outer and inner phloem consist of thin walled cellulosic soft elements. Phloem fibers are thick-walled highly lignified and arranged in tangential bands. The xylem is very wide and occupied about the two third of the stem. The xylem elements include the xylem vessels, tracheidial vessels, wood fibers, wood parenchyma The pith is relatively wide consisting of rounded slightly thin-walled cells. Tannin cells or tubes, numerous cluster crystals of calcium oxalate each in one parenchyma cells forming crystalliferous parenchyma and starch grains are scattered in the cortical tissue, phloem and pith.

\section{The young stem branches (Figure 3C)}

- The structure of the young stem branches is almost similar to that of the old one with the following differences:
- The epidermal cells are polygonal, axially elongated with straight anticlinal walls, covered with thick smooth cuticle. Few stomata of anomocytic type and numerous non glandular hair (Combretaceous hair) are present.

- The cortex consists of 3-4 rows of collenchymatous cells followed by thin walled parynchymatous cells containing simple starch grains and calcium oxalate clusters.

- The pericycle is formed of groups of lignified fibers interrupted with parynchymatous cells.

\section{Powdered stem (Figure 3D)}

The stem powder is yellowish brown in color, odorless and has astringent taste, characterized by the following features: fragments of epidermal cells of the young stem branches showing anomocytic stomata; numerous unicellular non-glandular trichomes (Combretaceous hair); numerous clustered crystals of calcium oxalate, either free or in cells forming crystalliferous parenchyma; phloem and wood fibers with blunt or pointed occasionally forked apices, narrow lumen with thick lignified pitted walls; lignified vessels, and tracheidial vessels having spiral, annular, pitted, and bordered-pitted thickening; fragments of brown polygonal cells of the cork with thick lignified walls.

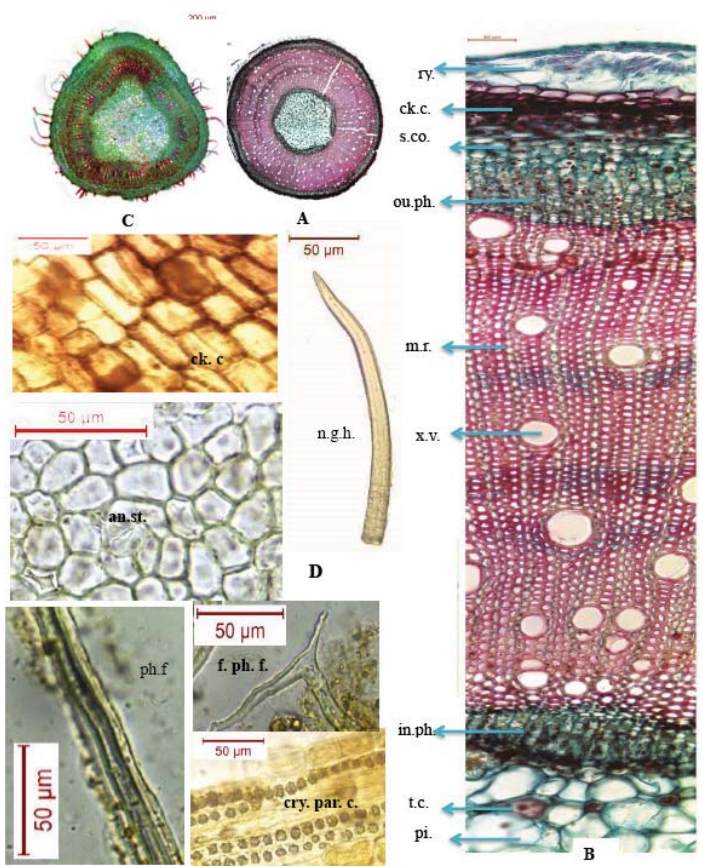

Fig. 3: Stem of Combretum aculeatum Vent. A. Low power of the old stem branches (X 50); B. High power of the old stem branches (X 320); C. Low power of the Young stem branches. (X 50); D Powder stem an.st., anomocytic stomata; ck. c., cork cell; ; cry.par.c., crystalliferous parynchymatous cells; f.ph.f., forked phloem fibersm.r., medullary ray; n.g.h., non glandular hair; o.ph., outer phloem; ; pi., pith; s.co., secondary cortex; ry., rhytidoma; in.ph., inner phloem; t. c., tannin cells; x.v., xylem vessels. ; w.f., wood fiber. 


\section{The bark (Figure 4A and B)}

A transverse section in the bark of Combretum aculeatum Vent. shows a reddish brown rhytidoma followed by cork, and narrow secondary cortex and a wide zone of secondary phloem.

The rhytidoma is formed of collapsed purple dead tissue interrupted by raised lenticels. The cork consists of about 7-8 rows of tangentially elongated, thick walled lignified cells arranged in radial rows. The cells are polygonal straight thick lignified walls containing yellowish brown content. The secondary cortex consist of about 10-12 rows of tangentially elongated thin walled parenchyma cells embedded with stone cells. The phloem is composed of soft phloem elements and groups of bast fibers arranged in tangentially bands accompanied with stone cells. The bast fibers have thick pitted lignified walls, narrow lumen and pointed and occasionally forked apex. Medullary rays are mostly uniseriate composed of large rectangular cells. Clusters of calcium oxalate, tannins cells, starch grains and crystalliferous parenchyma are scattered in the cortical and phloem tissue. Stone cells are polygonal to elongated with thick pitted lignified walls.

\section{Powdered bark (Figure 4C)}

The powdered bark is brown in color, odorless and has a stringent bitter taste. It is characterized by the following features: fragments of surface view cork cells; phloem fibers with funnel shaped thick lignified pitted walls with occasionally forked apex usually accompanied by tannin cells o tubes and stone cells; numerous clusters crystals of calcium oxalate, free or in the cells, usually forming crystalliferous parenchyma; starch grains are scattered in the cortical and phloem tissue; fragment of stone cells.
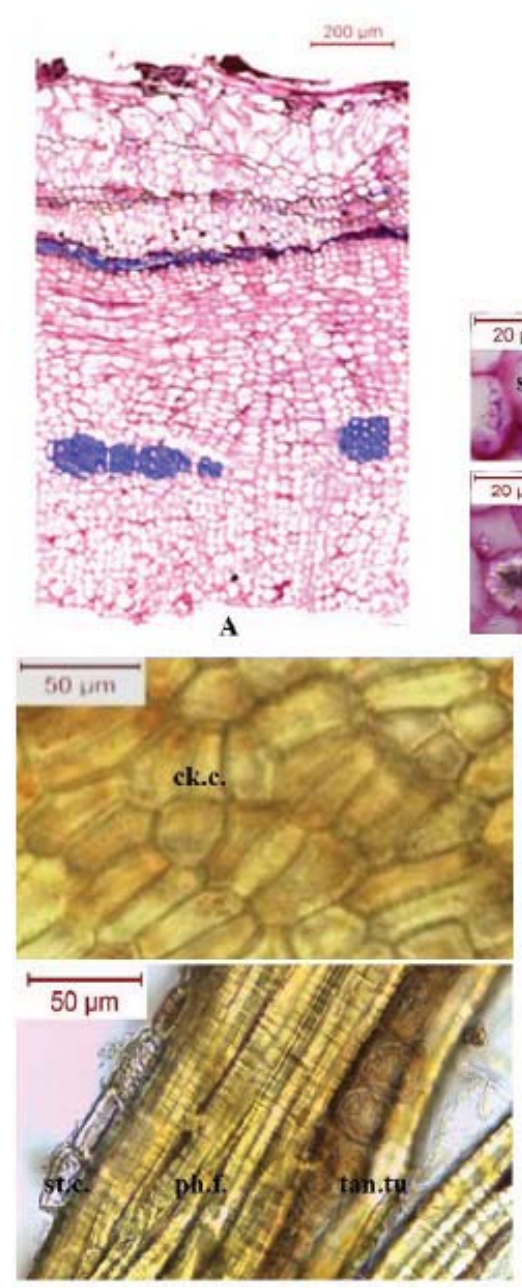

lent.

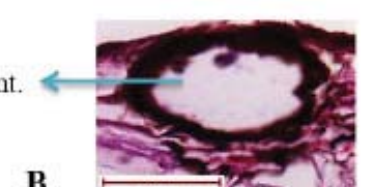

B
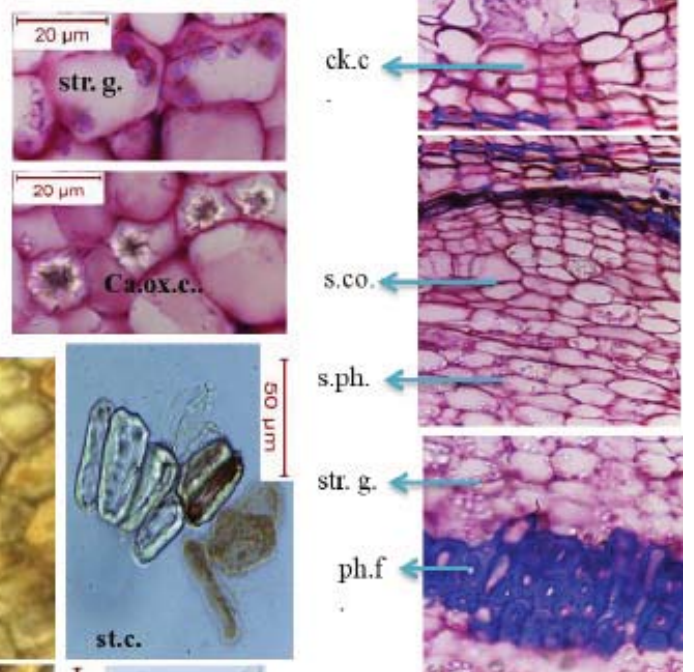

s.ph.
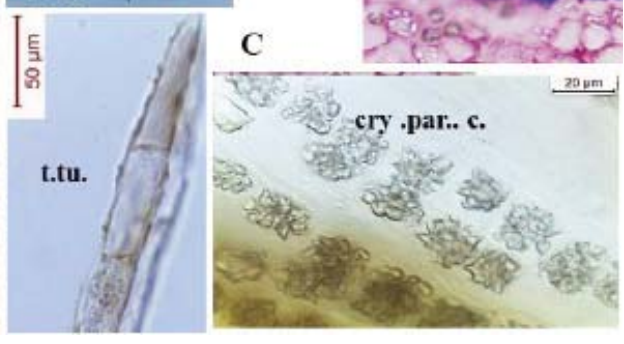

Fig. 4: Bark of Combretum aculeatum Vent. A Low power of the bark (X 60); High power of the bark (X 230); C Powdered bark: ca. ox.c., calcium oxalate cluster; ck.c., cork cells; cry. par. c., crystalliferous parynchymatous cells; lent. Lenticel; ph.f, phloem fibers; s.co., secondary cortex; s.ph., secondary phloem; str. g., starch grains; st.c., stone cells; tan.tu., tannins tubes. 


\section{Phytochemical Study}

\section{Determination of certain pharmacopoeial constants}

(Table 1) showed moisture contents of $7.52 \%$ total ash of $14.09 \%$, water -soluble ash of $0.7 \%$, acid insoluble ash of $2.99 \%$ and alcohol soluble extract of $9.5 \%$.

Table 1: Pharmacopoeial constants of aerial parts of Combretum aculeatum Vent

\begin{tabular}{lc}
\hline Pharmacopoeial constant & Percentage \\
\hline Moisture content & 7.52 \\
Total ash & 14.09 \\
Water soluble ash & 0.70 \\
Acid insoluble ash & 2.99 \\
Alcohol soluble extract & 9.5 \\
\hline
\end{tabular}

\section{Determination of extractive percentages}

The percentage yield of extractives obtained on successive Soxhlet extraction of the dried aerial parts of the plant was the highest in ethyl acetate fraction followed by the petroleum ether, n-butanol and finally the methylene chloride fractions. Chemical investigation using chemical tests revealed that petroleum ether extract is enriched in steroids and /or terpenoids; meanwhile, flavonoids, tannins and saponins appeared to be major components of the ethyl acetate and n- butanol extracts. The methylene chloride extract was enriched with sterols and or triterpenes and flavonoids (Table 2).

Table 2: Percentage yield and physico-chemical characters of the extractives of the aerial parts of Combretum aculeatum Vent

\begin{tabular}{|c|c|c|c|c|}
\hline \multirow{2}{*}{$\begin{array}{l}\text { \% Yield and } \\
\text { physico- } \\
\text { chemical data }\end{array}$} & \multicolumn{4}{|c|}{ Physicochemical analysis of different extracts } \\
\hline & $\begin{array}{c}\text { Petroleum } \\
\text { ether }\end{array}$ & $\begin{array}{c}\text { Methylene } \\
\text { chloride }\end{array}$ & $\begin{array}{l}\text { Ethyl } \\
\text { acetate }\end{array}$ & $n$-Butanol \\
\hline$\%$ Yield & 1.85 & 0.924 & 2.2 & 1.66 \\
\hline \multicolumn{5}{|c|}{ Physical characters } \\
\hline Consistency & Semi-solid & Semi-solid & Solid & Solid \\
\hline Odor & $\begin{array}{c}\text { Faint } \\
\text { aromatic }\end{array}$ & $\begin{array}{c}\text { Faint } \\
\text { aromatic }\end{array}$ & $\begin{array}{c}\text { Not } \\
\text { characteristic }\end{array}$ & $\begin{array}{c}\text { Not } \\
\text { characteristic }\end{array}$ \\
\hline Color & Brown & Brown & $\begin{array}{l}\text { Reddish } \\
\text { brown }\end{array}$ & Brown \\
\hline \multicolumn{5}{|c|}{ Test for active constituents } \\
\hline $\begin{array}{l}\text { Sterols \&/or } \\
\text { triterpenes }\end{array}$ & ++ & \pm & - & - \\
\hline Flavonoids & - & \pm & ++ & ++ \\
\hline Tannins & - & - & ++ & ++ \\
\hline Saponins & - & - & + & + \\
\hline Alkaloids & - & - & - & - \\
\hline
\end{tabular}

\section{Total phenolic and flavonoid}

Total phenolic content was found to be $2.47 \mu \mathrm{g}$ GAE/ $\mathrm{mg}(0.25 \%)$ and total flavonoid content $7.96 \mu \mathrm{g} \mathrm{QE} / \mathrm{mg}$ $(0.8 \%)$ of dried ethanolic extract.

\section{HPLC analysis of phenolic and flavonoid}

Seventeen phenolic compounds were identified in the aerial parts of C. aculeatum Vent (Table 3). Ellagic acid and vanillic acid were the major identified phenolic compounds. Pyrogallol, ferulic acid and salicylic acid were present also in appreciable amounts. Together with nine flavonoids were identified where luteolin, naringin and quercetin were the major identified flavonoids. Quercetrin, hesperidin and rutin were also present in appreciable amounts (Table 4).

Table 3: Identified phenolic acids in C. aculeatum Vent. ethanolic extract by HPLC analysis at $\lambda_{\text {max }} 280$

\begin{tabular}{lc}
\hline \multicolumn{1}{c}{ Phenolic compounds } & $\mathrm{R}_{\mathrm{t}}$ \\
\hline Gallic acid & 7.35 \\
Pyrogallol & 7.48 \\
3-Hydroxytyrosol & 8.54 \\
Protocatechuic acid & 8.7 \\
Catechin & 8.9 \\
Chlorogenic acid & 9.4 \\
Catechol & 9.6 \\
Epicatechin & 10 \\
p-Hydroxybenzoic acid & 10.359 \\
Caffeic acid & 10.53 \\
Vanillic acid & 11.7 \\
p-Coumaric acid & 12.02 \\
Ferulic acid & 12.21 \\
Isoferulic acid & 12.6 \\
Ellagic acid & 13.44 \\
$\alpha$ - Coumaric acid & 13.64 \\
Salicylic acid & 14.52 \\
\hline
\end{tabular}

Table 4: Identified flavonoids in C. aculeatum Vent. ethanolic extract by HPLC analysis at $\lambda_{\text {max }} 330 \mathrm{~nm}$

\begin{tabular}{lc}
\hline \multicolumn{1}{c}{ Flavonoid compounds } & $\mathrm{R}_{\mathrm{t}}$ \\
\hline Luteolin & 11.373 \\
Naringin & 11.487 \\
Rutin & 11.731 \\
Hesperidin & 11.979 \\
Quercetrin & 12.532 \\
Quercetin & 13.440 \\
Hesperetin & 15.123 \\
Kaempferol & 15.485 \\
Apigenin & 16.331 \\
\hline
\end{tabular}

\section{Biological Study}

\section{Estimation of molluscicidal activity}

All studied extracts showed significant molluscicidal activity (Table 5) against the snails of Biomphalaria at dose of $1 \mathrm{mg} / \mathrm{ml}$ and $1.2 \mathrm{mg} / \mathrm{ml}$.

\section{Estimation of anthelmintic activity}

Results in table 6 revealed that the ethyl acetatebutanol (EB) and methylene chloride fractions showed anthelmintic activity against Toxocara vitrurorum worm. Moreover, other fractions showed moderate activity. 
Table 5: Molluscicidal activity of ethanolic extract and its fractions against B. alexandria snails

\begin{tabular}{|c|c|c|c|c|c|}
\hline C. aculeatum extracts & Conc/Exp period & $0.25 \mathrm{mg} / \mathrm{ml}$ & $0.5 \mathrm{mg} / \mathrm{ml}$ & $1 \mathrm{mg} / \mathrm{ml}$ & $1.2 \mathrm{mg} / \mathrm{ml}$ \\
\hline \multirow{4}{*}{ Ethanolic extract } & 3hours & $0 \%$ & $0 \%$ & $90 \%$ & \multirow{4}{*}{$100 \%$} \\
\hline & 6hours & $0 \%$ & $0 \%$ & $100 \%$ & \\
\hline & 12hours & $0 \%$ & $0 \%$ & $100 \%$ & \\
\hline & 24hours & $0 \%$ & $0 \%$ & $100 \%$ & \\
\hline \multirow{4}{*}{ Petroleum ether fraction } & 3hours & $0 \%$ & $60 \%$ & $70 \%$ & \multirow{4}{*}{$100 \%$} \\
\hline & 6hours & $0 \%$ & $60 \%$ & $80 \%$ & \\
\hline & 12hours & $30 \%$ & $70 \%$ & $90 \%$ & \\
\hline & 24hours & $40 \%$ & $80 \%$ & $100 \%$ & \\
\hline \multirow{4}{*}{ Methylene chloride fraction } & 3hours & $0 \%$ & $50 \%$ & $70 \%$ & \multirow{4}{*}{$100 \%$} \\
\hline & 6hours & $20 \%$ & $60 \%$ & $80 \%$ & \\
\hline & 12hours & $20 \%$ & $60 \%$ & $80 \%$ & \\
\hline & 24hours & $40 \%$ & $70 \%$ & $100 \%$ & \\
\hline \multirow{4}{*}{ EB fraction } & 3hours & $0 \%$ & $50 \%$ & $80 \%$ & \multirow{4}{*}{$100 \%$} \\
\hline & 6hours & $20 \%$ & $70 \%$ & $80 \%$ & \\
\hline & 12hours & $40 \%$ & $70 \%$ & $90 \%$ & \\
\hline & 24hours & $50 \%$ & $80 \%$ & $100 \%$ & \\
\hline
\end{tabular}

Table 6: Anthelmintic activity of ethanolic extracts and it is fraction against T.vitulorum

\begin{tabular}{|c|c|c|c|c|c|}
\hline Sample & Conc/Exp period & $0.25 \mathrm{~g} / \mathrm{ml}$ & $0.5 \mathrm{~g} / \mathrm{ml}$ & $1.0 \mathrm{~g} / \mathrm{ml}$ & $1.2 \mathrm{~g} / \mathrm{ml}$ \\
\hline \multirow{4}{*}{ Ethanolic extract } & 3hours & $25.6 \%$ & $32.5 \%$ & $47.3 \%$ & \multirow{4}{*}{$54.5 \%$} \\
\hline & 6hours & $41.2 \%$ & $36 \%$ & $48.2 \%$ & \\
\hline & 12hours & $32.7 \%$ & $38.1 \%$ & $45.2 \%$ & \\
\hline & 24hours & $31.6 \%$ & $39.8 \%$ & $47.7 \%$ & \\
\hline \multirow{4}{*}{ Petroleum ether fraction } & 3hours & $49.1 \%$ & $49.1 \%$ & $66.3 \%$ & \multirow{4}{*}{$97.1 \%$} \\
\hline & 6hours & $61.7 \%$ & $67.2 \%$ & $73.5 \%$ & \\
\hline & 12hours & $61.5 \%$ & $65.4 \%$ & $77.2 \%$ & \\
\hline & 24hours & $60.0 \%$ & $51.3 \%$ & $81.6 \%$ & \\
\hline \multirow{4}{*}{ Methylene chloride fraction } & 3hours & $75.3 \%$ & $80.1 \%$ & $90.3 \%$ & \multirow{4}{*}{$100 \%$} \\
\hline & 6hours & $52.1 \%$ & $49.3 \%$ & $96.2 \%$ & \\
\hline & 12hours & $80.5 \%$ & $79.7 \%$ & $96.2 \%$ & \\
\hline & 24hours & $83 \%$ & $91.4 \%$ & $97.7 \%$ & \\
\hline \multirow{4}{*}{ EB fraction } & 3hours & $80.1 \%$ & $82.1 \%$ & $94.3 \%$ & \multirow{4}{*}{$100 \%$} \\
\hline & 6hours & $55.9 \%$ & $50.2 \%$ & $99.2 \%$ & \\
\hline & 12hours & $82.7 \%$ & $81.7 \%$ & $99.4 \%$ & \\
\hline & 24hours & $86.8 \%$ & $94.7 \%$ & $94.2 \%$ & \\
\hline
\end{tabular}

\section{DISCUSSION}

From the microscopical examination of Combretum aculeatum Vent., we could deduce the characteristic elements. The leaf is microscopically characterized by fragments of upper and lower epidermises with anomocytic stomata, abundant unicellular non-glandular (Combretaceous hair), few glandular club shaped trichomes; large idioblast containing cluster of calcium oxalate beside numerous clustered crystals of calcium oxalate, tannin cells and tubes. The old stem and bark is characterized by thick reddish brown rhytidoma, numerous clustered crystals of calcium oxalate, either free or in cells forming crystalliferous parenchyma; phloem fibers with blunt or pointed occasionally forked apices and thick lignified pitted walls; fragments of brown polygonal cells of the cork; secretory cells or tubes containing tannins and stone cells. All these botanical features are in agreements with the reported data ${ }^{[16]}$.

The total ash is an important parameter in the evaluation of purity of drugs indicating the presence or absence of foreign inorganic matter such as salts and siliceous matter. The total ash (14.09\%) indicates the presence of inorganic matter which is confirmed by the acid insoluble ash $(2.99 \%)$. The low moisture content of the drug $(7.52 \%)$ is a good criteria discouraging bacterial and fungal growth. Alcohol extractive value $(9.5 \%)$ was determined to find 
out the amount of alcohol soluble components. Extractive values are also useful to evaluate the chemical constituent present in the crude drugs and help in the estimation of specific constituents soluble in particular solvents. All studied extracts showed significant molluscicidal activity against the snails of Biomphalaria at dose of $1 \mathrm{mg} / \mathrm{ml}$ and $1.2 \mathrm{mg} / \mathrm{ml}$, the ethyl acetate-butanol and methylene chloride fractions showed anthelmintic activity against Toxocara vitrurorum worm.

\section{CONCLUSION}

In the present study, this pharmacognostical study for aerial parts of Combretum aculeatum Vent. can serve as a valuable source to establish the botanical characters of the different organs of the plant being reported for the first time to allow identification, authentication and discrimination of the genuine plant materials from other Combretum species to confirm its safety in traditional uses.

\section{CONFILICT OF INTEREST}

There are no confilice of interest

\section{References}

1. World Health Organization. Pharmaceuticals Unit, Quality control methods for medicinal plant materials, Geneva World Heal. Organ. (1998) 122. doi:10.1017/ CBO9781107415324.004.

2. G.E. Wickens, Alternative uses of browse species, Brows. Africa Curr. State Knowledge. Ed. by HN Le Houérou. ILCA, Addis Ababa. (1980) 155-182. https:// www.cabdirect.org/cabdirect/abstract/19850772458 (accessed July 4, 2018).

3. M. Sanon, M. Sacandé, L. Schmidt, Combretum aculeatum Vent, Seed Leafl. (2007).

4. C.A. Stace, Combretaceae, in: Flower. Plants . Eudicots, Springer Berlin Heidelberg, Berlin, Heidelberg, 2007: pp. 67-82. doi:10.1007/978-3-54032219-1_11.

5. A. Dawe, S. Pierre, D.E. Tsala, S. Habtemariam, Phytochemical Constituents of Combretum Loefl. (Combretaceae), Pharm. Crop. 4 (2013) 38-59. doi:10 .2174/2210290601304010038.

6. J.N. Eloff, J.O. Famakin, D.R.P. Katerere, Isolation of an antibacterial stilbene from Combretum woodii (Combretaceae) leaves, African J. Biotechnol. 4 (2005) 1167-1171.
7. W.C. Evans, Trease and Evans' Pharmacognosy E-Book, Elsevier Health Sciences, 2009.

8. D. Ranjan Behera, S. Bhatnagar, S. Sahoo, A. Kumar Mohapatra, P. Analysis, Phytochemical analysis, Antioxidant and Cytotoxic activity of medicinal plant Combretum roxburghii (Family: Combretaceae) Macrofilaricidal effects of medicinal plants: A drug discovery approach. View project Sunita Bhatnagar Regional Plant Resource Centre, Int. J. Drug Dev. Res. 4 (n.d.) 193-202. https://www.researchgate.net/ publication/243971701 (accessed July 4, 2018).

9. J.N. Eloff, D.R. Katerere, L.J. McGaw, The biological activity and chemistry of the southern African Combretaceae, J. Ethnopharmacol. 119 (2008) 686-699.

10. G.R. De Morais Lima, I.R.P. De Sales, M.R.D. Caldas Filho, N.Z.T. De Jesus, H. De Sousa Falcão, J.M. Barbosa-Filho, A.G.S. Cabral, A.L. Souto, J.F. Tavares, L.M. Batista, M.R.D.C. Filho, N.Z.T. De Jesus, H. De Sousa Falcão, J.M. Barbosa-Filho, A.G.S. Cabral, A.L. Souto, J.F. Tavares, L.M. Batista, Bioactivities of the genus Combretum (Combretaceae): A review, Molecules. 17 (2012) 9142-9206. doi:10.3390/ molecules 17089142 .

11. E. Pharmacopoeia, the English Text of Arab Republic of Egypt, 4th Ed. Cent. Adm. Pharm. Aff. Minist. Heal. Popul. (2005) 1295.

12. N.N.Azwanida, A review on the extraction methods use in medicinal plants, principle, strength and limitation, Med Aromat Plants. 4 (2015) 2167-0412.1000196.

13. G.C.L. and J.C.P. de M. Andressa Blainski, Application and Analysis of the Folin Ciocalteu Method for the Determination of the Total Phenolic Content from Limonium Brasiliense L., Molecules. 18 (2013) 68526864. doi:10.3390/molecules 18066852 .

14. P. Mattila, J. Astola, J. Kumpulainen, Determination of flavonoids in plant material by HPLC with diodearray and electro-array detections, J. Agric. Food Chem. 48 (2000) 5834-5841.

15. M. Amin, H. Abubaker, Control of schistosomiasis in the gezira irrigation scheme, Sudan, J. Biosoc. Sci. 49 (2017) 83-98. doi:10.1017/S0021932016000079.

16. C.R. Metcalfe, L. Chalk, Anatomy of the Dicotyledons, At The Clarendon Press; Oxford, 1950. 